Nepalese Journal of Biosciences 2: 151-153 (2012) Brief Communication

\title{
Soil borne fungi of cultivated lands of Biratnagar, Nepal
}

\author{
Umesh Koirala \\ Department of Botany, Post Graduate Campus, T.U., Biratnagar, Nepal \\ E-mail:umesh6977@hotmail.com
}

Key words: Fungi, soil depth, cultivated fields, Biratnagar, Nepal

Several micro-organisms may associate in the different layers of soil. The disease caused by micro-organisms that live in the soil is referred to as soil borne-disease and pathogen as soil borne pathogen. The fungi (pathogenic and non-pathogenic) that are associated in the soil are known as soil borne fungi.

Soil is the source of organic and inorganic nutrients providing the energy for fungi, bacteria and actinomycetes.The decomposition process of organic matter contributes to the maintenance of the nutrient status of soil providing an environment suitable for different types of fungi. The analysis of soil shows diverse types of fungi both pathogenic and nonpathogenic.

Baruah (1982) found that the type of frequently occurring fungi varies with the depth of soil. Mucor, Aspergillus, Rhizopus, Trichosporium, Cladosporium, Helminthosporium preferred the superficial layer of soil. Penicillium, Alternaria, Trichoderma, Trichothecium, Fusarium and Mycelia sterilla were found in soil from 5.08-15.24 cm depth whereas at a depth of $30.48 \mathrm{~cm}$, only 2 isolates of Penicillium and Trichoderma were present. No fungus was recorded from $60.96 \mathrm{~cm}$ depth.

Soil borne pathogens are very destructive and cannot be controlled easily but in Nepal soil mycroflora has not been adequately investigated so far. Listing and description of the soil borne fungi found at Biratnagar are presented in this paper.

Biratnagar (Lat. $26^{\circ} 20^{\prime} \mathrm{N}$, Long. $87^{\circ} 16^{\prime} \mathrm{E}$, Alt. $72 \mathrm{msl}$ ) is a part of the alluvial plain of the northern Indian subcontinent. Soil of the area is made up of materials transported and deposited in relatively recent times by the tributaries of the Ganga. Being immature, soil has no profile. The general soil texture is sand $40 \%$, silt $40 \%$ and clay $20 \%$. Phosphorus ranges from 0.004-0.464 (Bhatta, 1977).

The climate of Biratnagar is sub-tropical monotonice. Herbaceous plants are the dominant components of the vegetation of Biratnagar bearing $73 \%$ of dominance value in terms of floristic composition (Jha \& Siwakoti, 1987). Except a few thin patches of natural forests here and there, most of the trees present in this region are planted. Lack of natural trees and shrubs is due to biotic pressure.

The study area was divided into five spots namely Jamungachhi, Avivadan tole, P.G. Campus field, Janapath tole and Mills area. Alluvial soil, high temperature and adequate rain, irrigation facilities and comparatively easy availability of agricultural inputs favour cultivation of two or more crops in a year in this area. The principal crops are paddy, wheat, maize, potato, oil seeds, lentil and pigeon pea while sugarcane and jute are cultivated as cash crops. Live-stock is an integral part of the agricultural system of the area. 
Soil samples were collected from different crop fields of the selected spots, and soil borne fungi were isolated by direct inoculation (War-cup pate) method. Sterilized steel tube was plunged into the soil at different depths to obtain soil samples from $0 \mathrm{~cm}, 0-10 \mathrm{~cm}, 10-20$ $\mathrm{cm}$ and 20-30 cm depths. The soil $\mathrm{pH}$ was determined using Digital $\mathrm{pH}$ meter model- 153R Toshon (India), and soil texture was determined by sieving and weighting method (Piper, 1944)

Table 1. Soil $\mathrm{pH}$ recorded at different soil depths.

\begin{tabular}{ccccccc}
\hline \multirow{2}{*}{ S.N. } & \multirow{2}{*}{ Depth $(\mathrm{cm})$} & \multicolumn{5}{c}{$\mathrm{pH}$ value } \\
\cline { 2 - 7 } & & $\mathrm{Jg}$ & $\mathrm{At}$ & $\mathrm{Cf}$ & $\mathrm{Jt}$ & $\mathrm{Ma}$ \\
\hline 1 & 0 & 8.1 & 7.4 & 7.2 & 7.8 & 7.3 \\
2 & $0-10$ & 7.7 & 7.1 & 7.1 & 7.6 & 7.3 \\
3 & $10-20$ & 7.1 & 7.1 & 6.8 & 7.6 & 7.1 \\
4 & $20-30$ & 7.1 & 6.8 & 6.6 & 7.2 & 7.2 \\
\hline
\end{tabular}

$\mathrm{Jg}=$ Jamungachhi, $\mathrm{At}=$ Abivadan tole, $\mathrm{Cf}=$ Campus field, $\mathrm{Jt}=$ Janapath tole, $\mathrm{Ma}=$ Mills area

Table 2. Soil borne fungi obtained from different spots of Biratnagar.

\begin{tabular}{|c|c|c|c|c|c|c|c|}
\hline S.No & Name of fungi & Family & JG & AT & $\mathbf{C F}$ & JT & MA \\
\hline 1 & Acrostalagmus sp. & Moniliacae & + & - & - & & - \\
\hline 2 & Alternaria brassicola & Dematiaceae & - & + & - & - & - \\
\hline 3 & Alternaria tenuis & Dematiaceae & - & - & + & - & - \\
\hline 4 & Aspergillus flavus & Aspergillaceae & + & - & - & - & - \\
\hline 5 & A. niger & Aspergillaceae & - & - & + & - & + \\
\hline 6 & A. fumigatus & Aspergillaceae & - & - & - & + & - \\
\hline 7 & Choenophora sp & Cherophoraceae & - & - & + & - & - \\
\hline 8 & Cladosporium sp & Dematiaceae & - & + & - & - & - \\
\hline 9 & Cunninghamella sp & Cunninghamellaceae & - & - & + & + & - \\
\hline 10 & Curvularia sp & Dematiaceae & - & + & - & - & - \\
\hline 11 & Fusarium sp & Tuberculariaceae & + & - & + & + & + \\
\hline 12 & Fusarium sp (ii) & Tuberculariaceae & - & + & - & - & - \\
\hline 13 & Gliocladium $s p$ & Moniliaceae & - & - & - & + & - \\
\hline 14 & Gongronella butleri & Mucoraceae & - & + & - & - & - \\
\hline 15 & Helminthosporium sp & Dematiaceae & - & - & - & + & - \\
\hline 16 & Mucor racemosus & Mucoraceae & - & + & - & - & - \\
\hline 17 & Penicillium citrinum & Aspergillaceae & - & - & + & - & - \\
\hline 18 & $P$. granulatum & Aspergillaceae & + & - & - & - & + \\
\hline 19 & P.purpurogenum & Aspergillaceae & - & - & - & + & - \\
\hline 20 & Rhizoctonia sp. & Mycelia Sterelia & - & - & - & - & + \\
\hline 21 & Rhizopus sp & Mucoraceae & + & + & + & + & + \\
\hline 22 & Stysanus sp & Stilbellaceae & - & + & - & - & - \\
\hline 23 & Verticillium $s p$ & Moniliaceae & - & - & + & - & - \\
\hline
\end{tabular}

The media used for the cultivation of micro-organism was sterilized by means of autoclave (Aneja, 1993). Soil was incubated by War-cup (1951) method. About $0.15 \mathrm{~g}$ air dried soil samples was placed in five sterile petri-dishes with the help of transfer loop. About $20 \mathrm{ml}$ of melted, cooled medium was added in those petri-dishes with the help of transfer loop. Soil 
particles were dispensed throughout the medium by gentle rotation of the petri-dishes. The plates were allowed to solidify and were incubated at $25^{\circ} \mathrm{C}$ in an inverted position for 15 days. The fungi grown were observed carefully. Slides of fungi were made. Photographs of the fungi were taken and fungi obtained were studied critically under microscope. Literature used for the identification of fungi included Gilman (1957), Barnett (1960), Barron (1966) and Ellis (1971). The pH value of soil of each spot slightly decreased with increase in soil depth.

The soils of all investigated spots were slightly alkaline in nature. The soil $\mathrm{pH}$ ranged from 6.6-8.1. With the increase of soil depth, $\mathrm{pH}$ value decreased (Tab. 1).

The total numbers of fungi obtained were above 30, out of which 23 fungi with 17 genera and 10 species were identified. The most dominant species were Aspergillus, Fusarium, Penicillium and Rhizopus (Tab. 2). More fungi were obtained from Campus field and Avivadan tole.

The present study showed that greater numbers of species are present near the surface layer than deeper in the soil profile. Growth and population of fungi are governed by various factors like temperature, $\mathrm{O}_{2}$ concentration, $\mathrm{CO}_{2}$ concentration, light, moisture, $\mathrm{pH}$, organic and inorganic nutrients, etc. These factors favour the development and sporulation of soil fungi as a result of which more fungi are found near the surface layer than deeper in the soil profile.

\section{References}

Aneja, K.R. 1993. Experiments in Microbiology, plant pathology and tissue culture. Wishwa Prakashan, New Delhi.

Barnett, H.L. 1969. Illustrated genera of imperfect fungi. Burges publishing company, Minneapolis.

Barron, G.L. 1966. The genera of Hyphomycetes from soils. The William and Wilking Company, Baltimore.

Baruah, H.K. 1982. Study on the soil fungi and their biochemical activities fungi from the paddy field. Antibiotics symposium, Ind., Sci., Congress.

Bhatta, D.D. 1977. Natural history and economic Botany of Nepal. Orient Longman Ltd., New Delhi.

Ellis, M.B. 1971. Dematiaceous Hyphomycetes. Common Wealth Mycological Institute, Kew Survey England.

Garret, S.D. 1956. Soil fungi and soil fertility. Perganon press Ltd., The Macmillan Company, New York.

Gilman, J.C. 1957. A manual of soil fungi. The Town State Uni. Press, USA.

Jha, S. \& M. Siwakoti. 1987. Angiospecmic flora of Biratnagar. J. Nat. Hist. Mus. 2(1-4): 99118.

Piper, C.S. 1944. Soil and plant analysis. The University of Adelaide, Adelaide, Australia.

War Cup, J.H. 1951. Studies on the growth of Basidiomycetes in soil. Annal of Botany, London N.S. 15: 305-317. 